\title{
Su Ürünlerinde Metallotionein Proteinleri
}

\section{Semra KÜÇÜK}

\section{' Aydın Adnan Menderes Üniversitesi Ziraat Fakültesi Su Ürünleri Mühendisliği Bölümü 09100, Aydın}

Öz: Günümüzde su ve çevre evsel, tarımsal ve endüstriyel faaliyetler ile hızlı bir șekilde kirlenmektedir. Bu kirliliğin içinde ağır metal kirliliği oldukça önemli bir yer tutmaktadır. Suyun, toprağın ve atmosferin ağır metallerle kirlenmesi sonucu, doğal ortamlarında yașayan veya yetiștiriciliği yapılan su ürünleri ağır metallerle kontamine olmaktadır. Bu nedenle, su ürünleri, ağır metal zehirlenmesine karșı kendini korumak için metallotionein olarak isimlendirilen korucu bir protein olușturmaktadırlar. Metallotioneinler su ürünlerinden kahverengi alabalıklarda, tatlısu midyelerinde, yengeçlerinde ve beyaz karideslerde bașarılı șekilde kirlilik indikatörü olarak kullanılmaktadır. Metallotionein tanımına ve özelliklerine ve ayrıca sucul canlılarda ağır metal indikatörü olarak metallotioneinlerin kullanıldığı araștırmalara bu derlemede yer verilmiștir.

Anahtar Kelimeler: metallotionein, indikatör, ağır metal, su ürünleri

\section{Metallothionein Proteins in Aquacultural Products}

\begin{abstract}
Nowadays, water and environment have been polluted in a fast manner by domestic, agricultural and industrial activities. As a matter of fact that water, soil and atmosphere are polluted, aquacultural products in the nature or cultivated habitat are contaminated by heavy metals. Therefore, there is a protective protein called metallothionein in aquacultural products to protect them from heavy metal toxicity. Metallothionein is well used as heavy metals indicators in aquatic organisms such as brown trout, white shrimp, freshwater mussel and crab., Descirption of the metallothionein and its features, and the studies evaluating the metallothionein as heavy metals indicators in aquatic organisms is presented in this review.
\end{abstract}

Keywords: metallothionein, indicator, heavy metal, aquacultural products

\section{GiRiș}

Dünyanın en büyük sorunlarından biri gün geçtikçe ilerleyen teknolojiye ve nüfus artıșına paralel olarak çevre kirliliğinin artmasıdır. Bu kirlilik unsurlarından biri de ağır metal kirliliğidir. Ağır metaller endüstriyel faaliyetlerle (elektrik, kağıt, boya, plastik, metal kaplama sanayi), tarımsal (pestisit, gübre) ve madencilik faaliyetleriyle doğaya, suya, toprağa ve atmosfere salınmaktadır. Doğada biyolojik olarak parçalanmadan kalan ağır metaller $(\mathrm{Cu}, \mathrm{Zn}, \mathrm{Cd}, \mathrm{Pb}, \mathrm{Hg})$ canlı dokularında birikim yapmaktadır. Özellikle, balıkların farklı dokularında farklı miktarlarda birikim yaptıkları bazı araștırmada saptanmıștır (Öztürk ve ark., 1995; Ünlü ve ark., 1995; Kalay ve Canlı, 2000; Çalta ve ark., 2000; Thophon ve ark., 2003; Van Dyk ve ark., 2007; Mol ve ark., 2010; Liu ve ark., 20I I; Begum ve ark., 20I3; Selvanathan ve ark., 2013). Ayrıca ağır metaller besin zincirine girerek bu zincirin en üst halkası olan insanlarda en yüksek birikim miktarlarına ulașarak insan sağlığını tehdit edebilmektedir (Özkan ve ark., 20I8).

Çevre kirliliğine yol açan ve canlı yașamını olumsuz etkileyerek akut ve kronik zehirlenmelere sebep olan ağır metallerin insan besinini olușturan su ürünlerini içeren gıdalardaki birikim miktarlarının belirlenmesi ve bu konuda gerekli önlemlerin alınması da önemli bir durum olușturmaktadır.

Ağır metaller zehirli dozlarda balıklar üzerinde histopatolojik bozukluklara yol açmaktadır. Örneğin, sarı prenses balıkları (Lapidochromis caeruleus) $10-40 \mathrm{mg} \mathrm{l}^{-1}$ kadmiyum konsantrasyonlarına maruz bırakıldığında solungaçlarda ödem, hiperplazi, kıkırdak ve epitel hücrelerde dejenerasyonlar, pillar hücrelerde dağılmalar; karaciğerde vakuolleșme ve dejenerasyon; dalakta dejenerasyon, vakuolleșme ve nekroz görülmüștür (Küçük ve ark., 2018). Bu konuda benzer çalıșmalar mevcuttur.
Thophon ve ark. (2003), akut ve kronik kadmiyum zehirlenmesinde beyaz deniz levreği balıklarının (Lates calcarifer) solungaçlarında ödem, pillar hücrelerde dejenerasyon, anörizm, hiperplazi; karaciğerinde sinosoidlerde kanlı tıkanma (kongesyon), hidropik șișme, vakuolleșme ve siyah granül yapılar saptamıșlardır. Kadmiyumun tilapialarda (Oreochromis mossambicus) (Van Dyk ve ark., 2007), Synechogobius hasta adlı deniz balığı türünde (Liu ve ark., 20II), tatlısu kefallerinde (Leuciscus cephalus) (Y.lmaz ve ark., 20II), Opicephalus striatus türünde (Bais ve Lokhande, 2012), Nil tilapialarında (Oreochromis niloticus) (Omer ve ark., 2012; Younis ve ark., 2015), Clarias batrachus türünde (Selvanathan ve ark., 2013) benzer histopatolojik semptomlar olușturduğu rapor edilmiștir. Bakır zehirlenmesi tilapiaların (Oreochromis mossambicus) solungaçlarında ödeme, epitel dokuda kalkmalara, lamel damarlarında yoğun vazodilasyona, ayrıca az oranda proliferasyon sonucu lamellerde füzyonlara ve anörizme ve karaciğerde vakuoleșmelere, nekroza sebep olmuștur (Figueiredo-Fernandes ve ark., 2007). Çinko zehirlenmesi yeșil sazanlarını (Carassius gibelio) solungaçlarında proliferasyona, dejenerasyona, hiperemia ve füzyona yol açmıștır (Velcheva ve ark., 2010). Ağır metaller insanlarda da bazı hastalıklara yol açmaktadır. Örneğin, yüksek arsenik periferal vasküler hastalığına, bazı deri hastalıklarına; yüksek kurșun zehirlenmesi çocuklarda sentral ve periferal sinir sistemi bozukluklarına ve hafıza kayıplarına; yüksek kadmiyum böbrek ve iskelet bozukluklarına sebep olmaktadır (Küçük, 2018).

Sorumlu Yazar: skucuk@adu.edu.tr

Geliș Tarihi: 28 Mayıs 2018

Kabul Tarihi: 7 Arallk 2018 


\section{METALLOTIONEIN PROTEINLERI}

Ağır metaller canlı bünyesine girdiğinde hücre metabolizmasını ve gelișimini olumsuz etkilemektedir. Özellikle hücreler kendini koruma metabolizmalarından biri olan metallotionein (MT) adında bir protein üretirler. Bu MT'ler tüm hayvanlar aleminde yaygındır. Bu proteinler vücutta bulunan ağır metalleri tutarak vücuttan uzaklaștırırlar (Ryan ve ark., 1994; Bayhan ve Ünübol Aypak, 2016).

MT'ler omurgalılar, omurgasızlar, bitkiler ve bakterilerin içinde yer aldığı büyük bir canlı grubunun hemen hemen hepsinde bulunan sitosiklik polipeptidlerdir (Hamer, 1986). MT’ler düșük moleküler ağırlıklı (6-7 kiloDalton), sistein amino asidince zengin (\%25-35), tek zincirli, metallere bağlanma kapasitesi yüksek protein molekülleridir. Bu proteinlerin sülfidril grubu (SH) metal iyonlarına bağlanırlar. Ancak metal bağlama bölgelerinin \%50'si her zaman çinko ile doymuș durumdadır. Bir MT molekülü 6-7 Cd molekülünü bağlayabilmektedir (Kägi ve Vallee, 1960; Kojima ve ark., 1976; Hamer, 1986; de Miranda ve ark., 1990; Capdevila ve Atrian, 20I I; Yang ve ark., 20I5; Bayhan ve Ünübol Aypak, 20l6). Balıklarda karaciğer, böbrek, solungaç ve sindirim sisteminde MT'ler çok yaygındırlar (Kovarova ve ark., 2009).

Kadmiyum bağlayan ilk proteine at böbrek korteksinde rastlanmıștır (Margoshes ve Vallee, 1957). O zamandan beri memeli, bitki, fungus, protozoa, balık ve diğer türlerde pek çok MT proteini keșfedilmiștir (Hamer, 1986; Yu ve ark., 1998, 2000; Liu ve ark., 2000; Yıldız ve ark., 20I2). MT'ler olağandıșı özel nükleotid dizisi içerirler. Bunun yanında histitin, aromatik kalıntılar içermezler ve 3 boyutlu yapıları kendilerine hastır (Vergani ve ark., 2005). MT proteinleri sadece kadmiyum (Loebus ve ark., 20l3) civa ve kurșun gibi esansiyel olmayan ağır metalleri detoksifiye etmekle kalmaz. Aynı zamanda çinko ve bakır gibi esansiyel metalleri de dengede tutarlar (Coyle ve ark., 2002; Dąbrowska, 20I2) ve ayrıca canlıları (hayvanlar, bitkiler ve mikroorganizmalar) radikal oksijen türlerine (Hassinen ve ark., 20I I, Lv ve ark., 2013) ve DNA hasarlanmalarına (Higashimoto ve ark., 2009) karșı korurlar. MT’lerde yapılarında bulunan çok sayıdaki sistein kalıntısı sayesinde mercaptide bağı olușturarak değișik ağır metallere bağlanabilirler (Cobbett ve Goldsbrough, 2002).

MT gen familyası memelilerde 4 alt gruba ayrılır. Bunlar MTI'den MT-4'de kadar șekillenirler. MT'ler analitik kimyadan moleküller biyolojiye ve tıp alanlarına kadar birçok alanda kullanılmaktadır. Elde edilen birçok kanıta göre memelilerin MT-I/MT-2 genleri çinko homeostasis (dengesi) ve ağır metal toksisitesi ve oksidatif strese karșı korumada etkili olmaktayken (Vasak, 2005), MT3 geni temel olarak nöronlarda (sinir) ve sinirlerin bağ dokusu hücrelerinde (glia hücreleri) ve MT-4 geni ise epitel hücrelerde bulunmaktadır. MT yapısı ve fonksiyonları (Vasak, 2005) ve gen ekspresyonu (Li ve ark., 2006) üzerine birçok çalıșma mevcuttur. MT'ler konusu üzerinde birçok veri elde edilmiștir. Fakat bu konular üzerine tam bir açılık getirilememiștir.

\section{SU ÜRÜNLERINDE METALLOTIONEINLER}

Bayhan ve Ünübol Aypak (2016) Büyük Menderes Nehri kefal (Leuciscus cephalus) ve tatlısu levrek (Perca fluviatilis) balıklarının karaciğer ve kas dokusunda $\mathrm{Cu}, \mathrm{Zn}$ ve $\mathrm{Cd}$ birikim miktarlarını araștırmıșlardır. Ayrıca balıkların karaciğer dokularında metallotionein düzeylerini ELISA metodu kullanarak tespit etmișlerdir. Kefal karaciğerinde I I5.62 mg kg-1, levrek karaciğerinde $109.44 \mathrm{mg} \mathrm{kg}^{-1}$ olarak MT miktarlarını bulmușlardır. Sonuçta bu 2 tür balıkta da izin verilen değerlerin altında metal birikimi olduğunu bildirmișlerdir.

Overnell ve Abdullah (1988) Norveç'in Langesund fiyortlarında 4 istasyondan temin ettikleri pisi balıklarını (Plathichtys flesus) $0.08, \quad 5.00,20.00 \mathrm{mg} \mathrm{\textrm {L } ^ { - 1 }} \mathrm{Cu}$ konsantrasyonlarına 4 ay süresince maruz bırakmıșlardır ve bu balıkların karaciğer ve böbrek dokularında metal birikimlerine ve MT seviyelerine bakmıșlardır. Dokulardaki $\mathrm{Zn}$ birikimi fiyort bölgesinde yüksek çıkmıștır. Fakat bu sonuç ile karaciğer MT'leri arasında bir bağlantı bulamamıșlardır. Sonuç olarak da metal maruziyetinin bu istasyonlarda zarar verici boyutta olmadığını bildirmișlerdir. Aynı șekilde diğer üç istasyondaki Cu maruziyetinde (4 ay sonunda) karaciğerde Cu birikimi olmamıștır ve iki dokuda da MT'ler yüksek çıkmamıștır. Cu ile kirletilen 3 bölgedeki pisi balıklarının karaciğerinde $\mathrm{Cu}$ birikimi olmadığı gibi iki dokuda MT seviyeleri yüksek çıkmıștır. Sonuç olarak 4 fiyort istasyonunda ve diğer 3 bölgedeki $\mathrm{Cu}$ toksisitesinin pisi balıkları için zarar verici boyutta olmadığı bildirmișlerdir.

Moksnes ve ark. (1995) çiftlikte yetiștirilmiș tropikal karides türünü (Peneaus vannamei) $\mathrm{Cd}$ konsantrasyonuna $(0,1.5 \mathrm{mg}$ $\left.\mathrm{I}^{-1}\right)$ I, 3, 5, 9 gün sürelerle maruz bırakmıșlardır. MT miktarını pulse polarograf yöntemi ile tespit etmișlerdir. MT seviyesi dozlara bağlı olarak yükselmiștir. Zamana bağlı hepatopankreas $\mathrm{Cd}$ birikimi ile MT seviyesi arasında önemli bir korelasyon bulmușlardır. 9 günlük $1.5 \mathrm{mg} \quad \mathrm{l-1} \quad \mathrm{Cd}$ maruziyeti sonucunda hepatopankreasta 5600 jg g-1 MT miktarı bulunduğunu rapor etmișlerdir. Gelecekte karides çiftliklerinde ağır metal kirliliğinin izlenmesinde MT'lerin hassas, hızlı iyi bir potansiyele sahip olacağını bildirmișlerdir. Linde ve ark. (200I) metallotionein proteinlerinin ağır metal kirliliğinin biyoindikatörü olup olmadığını değerlendirmișlerdir. Kuzey İspanya'nın Ferrerias Nehri'nin yukarı kısmında (kirli olmayan) ve așağı kısmında (kirli) yașayan kahverengi alabalıklardan (Salmo trutta) ve yılan balıklarından (Anguilla anguilla) örnekler alarak metallotionein miktarını tespit etmișlerdir. Sonuç olarak MT'lerin kahverenği alabalıklarda kirlilik biyoindikatörü olarak bașarılı bir șekilde kullanılırken yılan balıklarında iyi bir belirteç olmadığını bildirmișlerdir.

Acker ve ark. (2005) Puget Boğazı'ında 7 istasyondan toplanan midyelerde (Mytillus sp.) metal (Cd, Pb, Cu) birikimine ve MT seviyelerine bakmıșlardır. Midyelerde metal birikiminin ve $M T$ seviyesinin düșük olduğu ve midyelerin kirlilik durumunu gösteren indikatörleri olmayacağını vurgulamıșlardır.

$\mathrm{Wu}$ ve Chen (2005) beyaz karidesleri (Litopenaeus vannamei) $4,7,14,21,28,56$ ve 84 gün süresince $0.0,0.1$, $0.2 \mathrm{mg} \mathrm{I}^{-1} \mathrm{Cd}$ ve $0.00,0.05, \quad 0.20 \mathrm{mg} \mathrm{I}^{-1} \quad \mathrm{Zn}$ konsantrasyonlarına maruz bırakmıșlardır. Hepatopankreas, 
solungaç ve kas dokusunda metal birikimini ve MT miktarlarını araștırmıșlardır. Cd ve $\mathrm{Zn}$ için farklı organlar için farklı miktarlarda MT ve metal birikimi saptamıșlardır. MT'lerin biyoindikatör olarak kullanılması için daha çok bilginin gerekli olduğunu bildirmișlerdir.

$\mathrm{Ma}$ ve ark. (2008) tatlısu yengeçlerini (Sinopotamon henanense) akut $\mathrm{Cd}$ konsantrasyonlarına $(0.0,5.8, \mathrm{I}$ I.6, 23.2

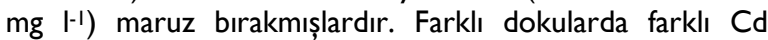
birikimi ve MT miktarı tespit etmișlerdir. Dokularda Cd birikimi sırasını solungaç $>$ hepatopankreas $>$ kas $>$ ovaryum olarak vermișlerdir. Dokulardaki MT seviyesi sırası ise hepatopankreas > solungaç > kas > ovaryum'dur. Hepatopankreas ve solungaçlarda Cd birikimi ile MT seviyesi arasında pozitif korelasyon bulmușlardır. Sonuç olarak da MT seviyesinin sularda Cd kirliliğinin bir indikatörü olabileceğini tatlısu yengeçlerinde göstermișlerdir.

Kovarova ve ark. (2009) sazan balığını (Cyprinus carpio) 2.5, 5.0, 7.5, 10.0 ve $12.5 \mathrm{mg} \mathrm{I-1'lik} \mathrm{Cd} \mathrm{konsantrasyonlarına}$ maruz bırakmıșlardır. Kas, karaciğer ve böbrekte $\mathrm{Cd}$ birikimini atomik absorbsiyon spektrofotometresi ile aynı dokularda metallotionein miktarlarını Brdicka reaksiyon yöntemiyle saptamıșlardır. Sudaki Cd artıșına bağlı olarak dokularda Cd birikiminin arttığını tespit etmișlerdir. Metallotionein miktarları 2.5, 5.0, $7.5 \quad \mathrm{mg} \quad \mathrm{I}^{-1} \mathrm{Cd}$ konsantrasyonlarında oldukça yükselirken (I30 ng g-l'dan fazla) 10.0 ve 12.5 gibi yüksek $C d$ konsantrasyonlarında daha düșük seviyede (50 ng $\mathrm{g}^{-1}$ ) bulmușlardır. Bu çalıșmada MT proteinlerinin ağır metal kirliliğinin indikatörü olarak kullanılmasının fazla mümkün olmadığı sonucunu bildirmișlerdir.

Raimundo ve ark. (2010) Portekiz kıyılarından yakalanan ahtapodların (Octopus vulgaris) sindirim kanalı, solungaç, böbrek ve gonadlarında ağır metal (V, Cr, Co, Ni, Zn, Cu, As ve $C d$ ) birikimlerini ve MT seviyelerini saptamıșlardır. Bu çalıșma ahtapodların MT’leri üzerine yapılmıș ilk çalıșma olmuștur. Sindirim kanalında Zn (48050 $\mu \mathrm{g} \mathrm{g}^{-1}$ kuru ağırlık) ve Cd (555 $\mu \mathrm{g} \mathrm{g}^{-1}$ kuru ağırlık) birikimlerini yüksek bulmușlardır. A ve B bölgesinden alınan örneklerin sindirim kanalı ve solungaçlarda Cd MT seviyelerinden önemli derecede daha yüksek çıkmıștır. Sindirim kanalı ve solungaçlardaki MT'ler $\mathrm{Cd}$ ve $\mathrm{Cr}$ detoksifikasyonunda önemlidir. Böbrek ve gonadlarda ağır metal birikiminin olmaması da bu organlarda detoksifikasyonun olduğunu; MT'lerin $\mathrm{Co}, \mathrm{Ni}$, As için üretildiğinin bilinmesine rağmen bu çalıșmada görülmemesi ise ahtapodlarda bașka bir detoksifikasyon mekanizmasının olduğunu veya bașka MT benzeri proteinlerin kullanıldığını düșündürebileceğini rapor etmișlerdir.

Trinchella ve ark. (2013) İtalya'nın güneyinde yer alan Napoli Körfezi'nde 5 istasyondan toplanan Akdeniz midyelerinin (Mytillus galloprovincialis) sindirim kanalı ve manto dokularında $\mathrm{Cd}$ ve $\mathrm{Pb}$ birikimlerini saptamıșlardır. Ayrıca bazı dokularda MT seviyelerine bakmıșlardır. Napoli Körfezi yoğun șekilde endüstriyel faaliyetlerin sürdüğü bir alandır. Sindirim kanalında mantoya göre daha yüksek metal birikimi ve MT seviyesi bulmușlardır.

Siscar ve ark. (2014) genç dil balıklarını (Solea senegalensis) 15 ve $20{ }^{\circ} \mathrm{C}$ 'de deniz suyuna 60 gün süreyle maruz bırakmıșlardır. Bu süre sonunda karaciğer ve böbrekte esansiyel ve esansiyel olmayan metallerin birikimi ve MT düzeylerini ICP-MS (Inductively Coupled Plasma Mass Spectrometre) ve pulse polarograf yöntemi kullanılarak ölçmüșlerdir. Ag, Cd, Cu ve $\mathrm{Mn}$ karaciğerde, $\mathrm{Co}, \mathrm{Fe}, \mathrm{Hg}$, Se, Zn böbrekte yüksek miktarlarda biriktiğini; yüksek sıcaklık ve maruziyet süresinin bazı metallerin ve MT'lerin karaciğerde miktarını yükselttiğini bildirmișlerdir. Örneğin $\mathrm{Cu}$ karaciğer tarafından tutulurken Se karaciğer ve böbrek tarafından da tutulmuștur. Böbreklerin MT'ye bağlı olarak yüksek bir detoksifikasyon kapasitesine sahip olduğunu bildirmișlerdir. Se'nin koruyucu etkisinden kaynaklı olarak böbrekte Se:Cd, Se:Ag oranlarının yüksek olduğunu bulmușlardır. Ayrıca dil balıklarında diğer türlere göre böbrekte $\mathrm{Cd}$ birikiminin önemli derecede düștüğünü bildirmișlerdir.

$\mathrm{Li}$ ve ark. (2015) tatlısu midyesini (Anodonta woodiana) 0.00, 4.21, 8.43, 16.86, 33.72, 67.45 mg l-1 Cd konsantrasyonlarına 24, 48, 72, 96 saat sürelerle maruz bırakmıșlardır. Maruziyet sonrası solungaç, manto, ayak, iç organlar ve sindirim kanalında $C d$ birikimine ve MT miktarına ve ayrıca Cd birikimi ile MT miktarı arasındaki korelasyonu araștırmıșlardır. Dokulardaki Cd birikimi sırasını solungaç $>$ manto $>$ ayak $>$ iç organlar $>$ sindirim kanalı olarak vermișlerdir. Cd birikimi tüm organlarda maruziyet miktarına bağlı olarak artmıștır. Manto ve solungaçtaki $\mathrm{Cd}$ birikimi ile MT miktarları arasında pozitif korelasyon bulmușlardır. Bu organdaki MT miktarlarının Cd kirliliğinin iyi bir indikatörü olabileceğini bildirmișlerdir.

Santovito ve ark. (2015) Akdeniz midyesini (Venerupis philippinarum) $0.000,0.030,0,157 \mu \mathrm{M}$ subletal $\mathrm{Cu}$ konsantrasyonlarına maruz bırakmıșlardır. Sindirim kanalı ve solungaçlardaki metal birikimi ile MT seviyeleri arasında pozitif korelasyon bulmușlardır.

Ghasemian ve ark. (2016) Hazar Denizi gammarus türünde (Pontogammarus maeoticus) ağır metal birikimine ve MT miktarına bakmıșlardır. Cd ve Pb MT'lerinin mevsimlere ve cinsiyete göre değișmediğini; $\mathrm{Cu}$ ve $\mathrm{Zn}$ birikim ve MT’lerin mevsimlere ve cinsiyete bağlı olduğunu bildirmișlerdir. MT'lerin dișilerde ve yaz mevsimlerinde daha yüksek olduğunu bulmuşlardır.

Wahid ve ark. (2017) Tayland'ın Tak bölgesinin Mae Sot kısmından toplanan bataklık yılan balıklarının (Monopterus albus) karaciğerinde $\mathrm{Cd}$ birikimi ve $M T$ miktarı tespit etmișlerdir. Bu Tak bölgesinin Mae Sot kısmında Zn madenciliği yapılmaktadır ve bu nedenle bölgede $\mathrm{Cd}$ kirliliğinin söz konusu olduğunu bildirmișlerdir. Bu bölgede I tanesi Zn madeninin yukarısında, 3 tanesi madenin așağı kısmında olmak üzere 4 istasyon belirlemișlerdir. Üst kısımdaki istasyonun Cd ile kontamine olmadığı, așağı kısımdaki istasyonların $\mathrm{Cd}$ ile kontamine olduğunu bildirmișlerdir. Balıkların karaciğerinde $\mathrm{Cd}$ birikimini atomik absorpsiyon spektrofotometresi kullanılarak tespit etmișlerdir. Uzun süreli $\mathrm{Cd}$ maruziyetinin bir göstergesi olarak karaciğerde MT’lere qRT-PCR (Qualitative RealTime PCR) kullanarak bakmıșlardır. Sonuçta, madenin așağısındaki istasyonlardan toplanan yılan balıklarının karaciğerinde $\mathrm{Cd}$ birikimi üst bölgelerden toplanan balıkların karaciğerindekinden daha yüksek çıkmıștır. MT seviyesi üst istasyonda 0.75 kat fazla çıkarken așağı istasyonlarda 0.94 kat daha yüksek çıkmıștır. Fakat karaciğerde Cd birikimi ile MT seviyeleri arasında paralel bir korelasyon bulamamıștır. 
Uzun süreli $\mathrm{Cd}$ maruziyetine bırakılmıș yılan balıklarında MT'lerin uygun biyoindikatör olmayabileceğini vurgulanmıștır.

\section{SONUÇ}

Bazı çalıșmalarda, MT'lerin tropikal karideslerde (Peneaus vannamei) (Moksnes ve ark., 1995), tatlısu yengeçlerinde (Sinopotamon henanense) (Ma ve ark., 2008), kahverenği alabalıklarda (Salmo trutta) (Linde ve ark., 200l), tatlısu midyesinde (Anodonta woodiana) ( $\mathrm{Li}$ ve ark., 2015) ve Akdeniz midyelerinde (Venerupis philippinerum) (Santovito ve ark., 20I5) kirlilik biyoindikatörü olabileceği gösterilirken; bazı çalıșmalar MT’lerin midyelerde (Mytillus sp.) (Acker ve ark., 2005), sazan balıklarında (Cyprinus carpio) (Kovarova ve ark., 2009), bataklık yılan balıklarında (Monopterus albus) (Wahid ve ark., 2017) kirlilik biyoindikatörü olarak kullanılamayacağını göstermiștir. Yani MT’lerin kirlilik indikatörü olarak kullanımı canlı türüne göre değișmektedir.

\section{KAYNAKLAR}

Acker, L.A., Mcmahan, J.R., Gawel, J.E. 2005. The effect of heavy metal pollution in aquatic environmentals on metallothionein production in Mytillus sp. Proceedings of the 2005 Puget Sound Georgia Basin Research.

Bais, U.E., Lokhande, M.V. 20I2. Effect of cadmium chloride on histopathological changes in the freshwater fish Ophiocephalus striatus (Channa). International Journal of Zoological Research, 8:23-32.

Bayhan, T., Ünübol Aypak, S. 2016. Büyük Menderes Deltasından avlanan kefal ve levreklerde $\mathrm{Cu}, \mathrm{Zn}$ ve $\mathrm{Cd}$ düzeylerinin belirlenmesi ve metalotiyonin ile ilișkisinin araștırılması. Gıda, 4 I (5):359-365.

Begum, A., Mustafa, A.I., Amin, M.N., Chowdhury, T.R., Quraihi, S.B., Banu, N. 2013. Levels of heavy metals in tissues of shingi fish (Heteropneustes fossilis) from Buriganga River, Bangladesh. Environmental Monitoring Assessment, 185:546 |-5469.

Capdevila, M., Atrian, S. 201I. Metallothionein protein evolution: a miniassay. Journal of Biological Inorganic Chemistry, 16(7):977-989.

Cobbett C., Goldsbrough P. 2002. Phytochelatins and metallothioneins: Roles in heavy metal detoxification and homeostasis. Annual Review Plant Biology, 53:159182.

Coyle P, Philcox JC, Carey LC, Rofe AM. 2002. Metallothionein the multipurpose protein. Cellular Molecular Life Sciences, 59:627-647.

Çalta, M., Canpolat, Ö., Nacar, A. 2000. Elazığ Keban Baraj Göl'nde yakalanan Capoeta trutta (HECKEL, 1843)'da bazı ağır metal düzeylerinin belirlenmesi, Doğu Anandolu Bölgesi IV. Su Ürünleri Sempozyumu, 28-30 Haziran 2000, Erzurum.

Dąbrowska G. 20I2. Plant metallothioneins: Putative functions identified by promoter analysis in silico. Acta Biologica Cracoviensia Series Botanica, 54:109-120.

de Miranda J. R., Thomas M. A., Thurman D. A., Tomsett A. B. 1990. Metallothionein genes from the flowering plant Mimulus guttatus. Fresenius Environmental Bulletin, 260(2):277-280.
Figueiredo-Fernandes A., Ferreira-Cardoso J.V., GarciaSantos S., Monteiro S.M., Carrola J., Matos P., Fernandes A.F. 2007. Histopathological changes in liver and gill epithelium of Nile tilapia, tilapia, Oreochromis niloticus, exposed to waterborne copper. Pesquisa Veterinaria Brassileira, 27(3): 103-109.

Ghasemian, S., Karimzadeh, K., Zahmatkesh, A. 2016. Metallothionein levels and heavy metals in Caspian Sea gammarid, Pontogammarus maeticus (Crustacea, Amphipoda, Pontogammaridae). Bioflux, 9(I): I-7.

Hamer D. H. 1986. Metallotionein. Annual Review Biochemistry, 55:913-95।.

Hassinen V., Tervahauta A., Schat H., Kärenlampi S. 20II. Plant metallothioneins-metal chelators with ROS scavenging activity? Plant Biology, 13:225-232.

Higashimoto M., Isoyama N., Ishibashi S., Inoue M., Takiguchi M., Suzuki S., Ohnishi Y. Sato, M. 2009. Tissue-dependent preventive effect of metallothionein against DNA damage in dyslipidemic mice under repeated stresses of fasting or restraint. Life Sciences, 84:569-575.

Kägi J. H., Vallee B. L. 1960. Metallothionein: A cadmiumand zinc-containing protein from equine renal cortex. Journal Biological Chemistry, 235:3460-3465.

Kalay, M. \& Canlı, M. (2000). Elimination of Essential (Cu, $\mathrm{Zn})$ and non-essential $(\mathrm{Cd}, \mathrm{Pb})$ metals from tissues of a freshwater fish Tilapia zilli. Turkish Journal of Zoology. 24: 429-436.

Kojima Y., Berger C., Vallee B. L., Kägi J. 1976. Amino-acid sequence of equine renal metallothionein-IB. Proceeding of the National Academy, Sci. USA 73:34I33417.

Kovarova, J., Kizek, R., Adam, V., Harustiakova, D., Celechovska, O., Svobodova, Z. 2009. Effect of cadmium chloride on metallothionein levels in carp. Sensors, 9:4789-4803.

Küçük S. 2018. Balıklarda Ağır Metal Birikimlerinin İncelenmesi, Uluslararası Su ve Çevre Kongresi. Sözlü Bildiri, 22-24. Mart. 2018. Bursa-Türkiye.

Küçük S., Midilli S., Güler M., Çoban D. 2018. Kadmiyuma Maruz Bırakılmıș Sarı Prenses (Labidochromis caeruleus) Balıklarında Saptanan Histolojik Değișiklikler Üzerine Bir Ön Çalıșma. Ege Su Ürünleri Dergisi 35(3):26I-266.

Li Y, Kimura T, Laity JH, Andrewa GK, 2006. The zinc sensing mechanism of mouse MTF-I involves linker peptides between the zinc fingers. Molecular and Cellular Biology, 26:5580-7.

Li, Y., Yang, H., Liu, N., Luo, J., Wang, Q.,Wang, L. 2015. Cadmium accumulation and metallothionein biosynthesis in cadmium-treated freshwater mussel Anodonta woodiana. Plos One, I0(2): I-I5.

Linde, A.R., Sanchez-Galan, S., Valles-Mota, P., GarciaVazquez, E. 200I. Metallothionein as bioindicator of freshwater of metal pollution: European eel and brown trout. Ecotoxicology and Environmental Safety, 49:6063.

Liu J.-Y., Lu T., Zhao N.-M. 2000. Classification and nomenclature of plant metallothionein-like proteins based on their cysteine arrangement patterns. Acta Botanica Sinica 42:649-652. 
Liu X. J., Luo Z., Li C. H., Xiong B. X., Zhao Y. H., Li X. D. 20II. Antioxidant responses, hepatic intermediary metabolism, histology and ultrastructure in Synechogobius hasta exposed to waterborne cadmium. Ecotoxicology and Environmental Safety 74: I I 56-I I 63.

Loebus J., Leitenmaier B., Meissner D., Braha B., Krauss G. J., Dobritzsch D., Freisinger E. 20I3. The major function of a metallothionein from the aquatic fungus Heliscus lugdunensis is cadmium detoxification. Journal of Inorganic Biochemistry, 127:253-260.

Lv, J., Ehteshami, P., Samak, M. J., Tighiouart, H., Jun, M., Ninomiya T., Foote C., Rodgers, A., Zhang, H., Wang, H., Strippoli, G. F., Perkovic, V. 2013. Effects of intensive blood pressure lowering on the progression of chronic kidney disease: a systematic review and metaanalysis. CMAJ, 185(I I):949-957.

Ma, W., Wang, L., He, Y., Yan, Y. 2008. Tissue-specific cadmium and metallothionein levels in freshwater crab Sinopotamon henanense during acute exposure to waterborne cadmium. Environmental Toxicology, 23(3):393-400.

Margoshes M., Vallee B. L. 1957. A cadmium protein from equine kidney cortex. Journal of the American Chemical Society, 79:48।3-48।4.

Mol, S., Özden, Ö., Oymak, S.A. 2010. Trace metal contents in fish species from Atatürk Dam Lake (Euphrates, Turkey). Turkish Journal of Fisheries and Aquatic Sciences, 10: 209-213.

Moksnes, P.O., Lindahl, U., Haux, C. 1995. Metallothionein as a bioindicator of heavy metal exposure in the tropical shrimp, Penaeus vannamei: a study of dose-dependent induction. Marine Environmental Research, 39:|43-|46.

Overnell, J., Abdullah, M.I. 1988. Metallothionein and metal levels in flounder Platichthys flesus from four field sites and in flounder dosed with water-borne copper. Marine Ecology Progress Series, 46:7I-74.

Omer, S.A., Elobeid, M.A., Fouad, D., Daghestani, M.H. 2012. Cadmium bioaccumulation and toxicity in tilapia fish (Oreochromis niloticus). Journal of Animal and Veterinary Advances, II: 1601-1606.

Özkan, E., Tașlıpınar, M.Y., Yeșilkaya, Ș. 2018. Ağır Metal Zehirlenmeleri. http://www.jcam.com.tr/files/KATD1599.pdf. (20 Kasım, 2018).

Öztürk, M., Bat, L., Öztürk, M. 1995. Altınkaya Barajı'nda (Samsun) yașayan Cyprinus carpio L., 1758 türünün çeșitli organ ve dokularındaki bazı ağır metallerin birikimi. II.Ulusal Ekoloji ve Çevre Kongresi Bildirileri, II-I3 Eylül, Ankara.

Raimundo, J., Costa, P.M., Vale, C., Costa, M.H., Moura, I. 2010. Metallothionein and trace elements in digestive gland, gills, kidney and gonads of Octopus vulgaris. Comparative Biochemistry and Physiology Part C, I52:139-146.

Ryan, K.R., Menold, M.M., Garrett, S., Jensen, R.E. 1994. SMSI, a high-copy suppressor of the yeast mas6 mutant, encodes an essential inner membrane protein required for mitochondrial protein import. Molecular Biology of the Cell, 5(5):529-538.

Santovito, G., Boldrin, F., Irato, P. 2015. Metal and metllothionein distribution in different tissues of the Mediterranean clam Venerupis philippinarum during
KÜçüK S

copper treatment and detoxification. Comparative Biochemistry and Physiology, Part C. 174-175:46-53.

Selvanathan, J., Vincent, S., Nirmala, A. 2013. Histopathology changes in freshwater fish Clarias batrachus (Linn.) exposed to mercury and cadmium. International Journal of Life Sciences and Pharma Research, 3(2): ||-2|.

Siscar, R., Torreblanca, A., del Ramo, J., Sole, M. 2014. Modulation of metallothionein and metal partitioning in liver and kidney of Solea senegalensis after long-term acclimation to two environmental temperatures. Environmental Research, 132:197-205.

Ünlü, E., Cengiz, E.İ., Akba, O., Gümgüm, B. 1995. Dicle Nehrindeki Capoeta trutta Heckel, I843'da ağır metal birikimi. II.Ulusal Ekoloji ve Çevre Kongresi Bildirileri, I I-I3 Eylül, Ankara.

Trinchella, F., Esposito, M.G., Simoniello, P., Scudiero, R. 2013. Cadmium, lead and metallothionein content in cultivated mussels (Mytillus galloproviancialis) from the Gulf of Naples (Southern Italy). Aquaculture Research, 44:1076-1084.

Thophon, S., Kruatrachue, M., Upatham, E.S., Pokethitiyook, P., Sahaphong, S., Jaritkhuan, S. 2003. Histopathological alterations of White seabass, Lates calcarifer, in acute and subchronic cadmium exposure. Environmental Pollution, I21: 307-320.

Vasak M. 2005. Advances in metallotionein structure and functions. Journal of Trace Elements in Medicine and Biology, 19:13-7.

Van Dyk, J.C., Pieterse, G.M., Van Vuren, J.H.J. 2007. Histological changes in the liver of Oreochromis mossambicus (Cichlidae) after exposure to cadmium and zinc. Ecotoxicology and Environmental Safety, 66: 432440.

Velcheva I.G., Arnaudov A.D., Georgieva E.S. 2010. Influence of Zinc on Gill Morphology of Gibelio Carp (Carassius gibelio). Ecologia Balkanica, 2:19-23.

Vergani L, Grattarola M, Borghi C, Dondero F, Viarengo A. 2005. Fish and molluscan metallothioneins. A structural and functional comparison. The FEBS Journal, 272: 6014-6023.

Wahid, M., Prasarnpun, S., Yimtragool, N. 2017 Cadmium accumulation and metallothionein gene expresion in the liver of swamp eel (Monopterus albus) collected from the Mae Sot District, Tak Province, Thailand. Genetic and Molecular Research, I6(3): I-I4.

Wu, J.P., Chen, H.C. 2005. Metallothionein induction and heavy metal accumulation in white shrimp Litopenaeus vannamei exposed to cadmium and zinc. Comparative Biochemistry and Physiology Part C. 140:383-394.

Yang M., Zhang F., Wang F., Dong Z., Cao Q., Chen M. 20I5. Characterization of a type I metallothionein gene from the stresses-tolerant plant Ziziphus jujuba. International Journal of Molecular Sciences, 16:1675016762

Yıldız M., Cenkci S., Terzi H. 20I2. Fitoșelatinler ve metallotiyoninler: moleküler yaklașımlar. AKÜ FEBID 12:1-16.

Yılmaz, M., Ersan, Y., Koç, E., Özen, H., Karaman, M. 201 I. Toxic effects of cadmium sulphate on tissue histopathology and serum protein expression in European chub, Leuciscus cepahlus (Linnaeus, 1758). 
Kafkas Üniversitesi Veteriner Fakültesi Dergisi, 17:131135.

Younis, E., Abdel-Wahab, A., Nasser, A., Hossam, E. 2015. Histopathological alterations in the liver and intestine of Nile tilapia Oreochromis niloticus exposed to long-term sublethal conentrations of cadmium chloride. Chinese Journal of Oceanology and Limnology, 33: 846-852.
Yu L. H., Umeda M, Liu J. Y., Zhao N. M., Uchimiya H. 1998. A novel MT gene of rice plants is strongly expressed in the node portion of the stem. Gene, 206:29-35.

Yu L. H., Liu J. Y., Umeda M, Uchimiya H., Zhao N. M. 2000. Cloning and sequence characteristics of the genomic gene of a rice metallothionein. China Science Bulletin, 45:I53-I55. 